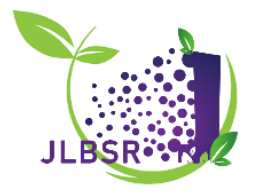

JOURNAL OF LIFE AND BIO-SCIENCES RESEARCH

\title{
Histological Changes, Micronuclei Induction and Nuclear Abnormalities in The Peripheral Erythrocytes of Clarias gariepinus (Burchell 1822) Exposed to Water Sample from Apodu Reservoir
}

\author{
Abass Toba Anifowoshe ${ }^{1, *}$, Julia Busola Oyebanji ${ }^{1}$, Olayinka Segun Oladipo ${ }^{2}$, Fatai Bolaji Oyeyemi ${ }^{3}$, Moshood Yemi \\ Abdulrahim $^{4}$, Saratu Iyabode Abdulkareem ${ }^{1}$; Moshood Keke Mustapha ${ }^{1}$ \\ ${ }^{1}$ Department of Zoology, Faculty of Life Sciences, University of Ilorin, Ilorin, Nigeria. (anifowoshe.at@unilorin.edu.ng, \\ anifowoshe.at@unilorin.edu.ng,busolagenetics@gmail.com,iyabodesaratu@yahoo.com,moonstapha@yahoo.com) \\ ${ }^{2}$ Department of Biosciences and Biotechnology, Kwara State University, Malete, Nigeria (segun.oladipo@kwasu.edu.ng) \\ ${ }^{3}$ Department of Science Technology, The Federal Polytechnic Ado-Ekiti, Nigeria (bollergene@gmail.com) \\ ${ }^{4}$ National Productivity Centre, Plot 2173 Cape Town Street, Wuse Zone 4, Abuja, Nigeria (moshoodbabata@yahoo.co.uk) \\ *Correspondence: anifowoshe.at@unilorin.edu.ng
}

\begin{abstract}
Pollution of water bodies in most developing countries is of grave concern since toxic pollutants interact with the genetic blueprints of aquatic organisms leading to a variety of illnesses. In this study, histological changes in the gills, liver and kidney as well as the genotoxic effect of water sample from Apodu reservoir, were investigated in the peripheral erythrocytes of cultured catfish (Clarias gariepinus) using micronucleus assay. They were exposed to the water sample for a period of 3, 7 and 14 days. The physico-chemical (pH, temperature, transparency) and heavy metals analysed $(\mathrm{Ca}>\mathrm{Mg}>\mathrm{Fe}>\mathrm{Zn}>\mathrm{Mn}>\mathrm{Cu}>\mathrm{Ni}=\mathrm{Pb}=\mathrm{Cd}=\mathrm{Cr})$ were all within the acceptable limit permissible. However, the micronucleus test shows statistically significant $(p<0.05)$ induction of micronuclei and nuclear abnormalities as compared to the control (borehole water). The histopathological analysis shows some mild alterations in the organs such as distortion and infiltration of lymphocytic cells of the gills. We also reported mild distortion of hepatic tissue of the liver as well as abnormal nephron and glomeruli with congestion and vascular dilation of the kidney. These alterations might be due to anthropogenic activities that pollute the water body. Therefore, the influx of agricultural and domestic waste into the Apodu reservoir should be discouraged as part of remediating efforts.
\end{abstract}

Keywords: Histopathology, Micronucleus, Apodu Reservoir, Clarias Gariepinus, Water Pollution

Received: March 18, 2020 / Accepted: April 18, 2020 / Online: April 20, 2020

\section{INTRODUCTION}

Human activities are sometimes detrimental to the life of aquatic organisms due to the continuous and intensity of chemical, biological and physical agents that contaminate the water bodies thus leading to genetic alterations and carcinogenesis in aquatic organisms most especially fishes. Therefore, evaluation of the genotoxic potential of the aquatic environment has thus become a major goal in the monitoring of environmental pollution (Osman et al., 2012). The analysis provides early warning signals of adverse longterm effects of the contamination (Rybakovas et al., 2009). Therefore, fishes as an excellent subject for the study of the genetic alterations of toxicants present in water samples have been used in several studies since they can metabolize, concentrate and store waterborne pollutants (Al-Sabti, 1991). They have also been used to screen chemicals that are potentially teratogenic (causing developmental malformation) and carcinogenic in humans since they respond to toxicants in a similar way to higher vertebrates (Sarangi et al., 2001).
The first study on the relevance of detecting the genotoxic risks associated with water pollution was discerned in the late 1970s. Since that period, several tests have been developed for evaluating genetic alteration to the blueprints of aquatic organisms. These tests rest on the fact that any changes to DNA may have long-lasting and profound consequences (Lam and Gray, 2003). These changes are usually caused by accumulation of heavy metals. Thus, accumulation and biomagnification of these heavy metals in fish are either from the surrounding water or by the ingestion of food in the environment. Javed and Usmani (2011) investigated the accumulation of heavy metals $(\mathrm{Cu}$, $\mathrm{Ni}, \mathrm{Fe}, \mathrm{Co}, \mathrm{Mn}, \mathrm{Cr}$ and $\mathrm{Zn}$ ) in three commercially important fishes namely Channa punctatus (murrel), Clarias gariepinus (catfish) and Labeo rohita (carp). The accumulation was observed in tissues of muscles, liver, kidney, gills and integument indicating the concentration of the $\mathrm{Fe}$ and $\mathrm{Zn}$ to be highest in all tissues analysed, followed by $\mathrm{Ni}, \mathrm{Cu}, \mathrm{Co}, \mathrm{Mn}$ and $\mathrm{Cr}$ in the studied species. In the muscles of Channa punctatus the order of accumulation was $\mathrm{Fe}>\mathrm{Zn}>\mathrm{Ni}>\mathrm{Cu}>\mathrm{Co}>$

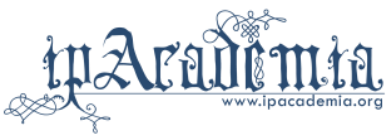


$\mathrm{Mn}$, whereas in Clarias gariepinus it was $\mathrm{Fe}>\mathrm{Zn}>\mathrm{Ni}>$ $\mathrm{Cu}=\mathrm{Mn}>\mathrm{Co}>\mathrm{Cr}$. In Labeo rohita the pattern of accumulation was $\mathrm{Zn}>\mathrm{Fe}>\mathrm{Ni}>\mathrm{Cu}>\mathrm{Co}>\mathrm{Mn}$. The order of accumulation of heavy metals was similar in murrel and catfish. Heavy metals in fish come mainly from domestic wastes, increasing loads of industrial, agricultural and commercial chemicals discharged and diets; and the levels of bioaccumulation of contaminants are higher in fish which comes higher in food chain EFSA, (2005), this poses a serious public health problem and a threat to the aquatic ecosystem (Mayon et al., 2006).

In spite of the extensive studies on the toxicity of fish in the wild and/or fish exposed to water samples from different reservoirs in Nigeria, there is a dearth of data on Apodu reservoir in which a baseline toxicity test is needed for proper management. In this study, histological changes and genotoxic potential of African catfish under laboratory conditions were investigated using micronucleus assay.

\section{MATERIALS AND METHODS}

\section{A. Biological Materials}

Fifty (50) juvenile African catfish (Clarias gariepinus) of 8-9 weeks old of mean body weight of $16 \mathrm{~g}$ and $11.5 \mathrm{~cm}$ length were obtained from Ige's farm located at Adelodun road, flower garden, Ilorin, Kwara State on the 12th of January 2017. They were acclimatized for a minimum of three (3) weeks in the laboratory of the Department of Zoology, University of Ilorin under normal laboratory condition prior to the commencement of the experiment. The fishes were maintained at $12 \mathrm{~h}$ photoperiod of day and night before and during the experiment and they were fed with commercial feed pellets ad libitum (Durante $2 \mathrm{~mm}$ ) obtained from Mykegrace feed mill. $50 \mathrm{~L}$ transparent plastic aquarium with a cover net was used for the experiment to allow easy ventilation. The cages were inspected morning and evening to check the behaviour and if there is mortality during the period acclimatization and exposure. Also, the water in the $50 \mathrm{~L}$ plastic aquaria (borehole water) was changed every two days to avoid contamination.

\section{B. Sampling Site}

The study was carried out in Apodu reservoir of about $7 \mathrm{~km}$ away from Malete town in Moro Local Government Area of Kwara State, Nigeria. The dam lies between the longitude 8045 "25.9'N, 8o, 45'27.7'N and latitude 4o 27'41.4”E, 4027 '35.5'E. It was constructed in 1987, re-impounded in 2016 and has a maximum length of $360 \mathrm{~m}$, maximum width of $400 \mathrm{~m}$ and maximum depth of $8.2 \mathrm{~m}$. The storage capacity is about $0.75 \mathrm{MCM}$ with the surface area of about 15 hectares. The water is mainly used by people around it for fisheries, domestic and agricultural purposes, as there is no industry around the river.

\section{Water Sampling}

Water samples were taken with a water sampler from the Apodu reservoir between 8:00 and 9:00 a.m. at a depth of
$30 \mathrm{~cm}$ below the water surface and stored at $4 \circ \mathrm{C}$ in clean 1000-ml sampling glass bottles according to Boyd (1990) for physicochemical and heavy metal analysis. The water sample was also taken from the same depth into a 50L clean jerry-can to the laboratory for fish exposure.

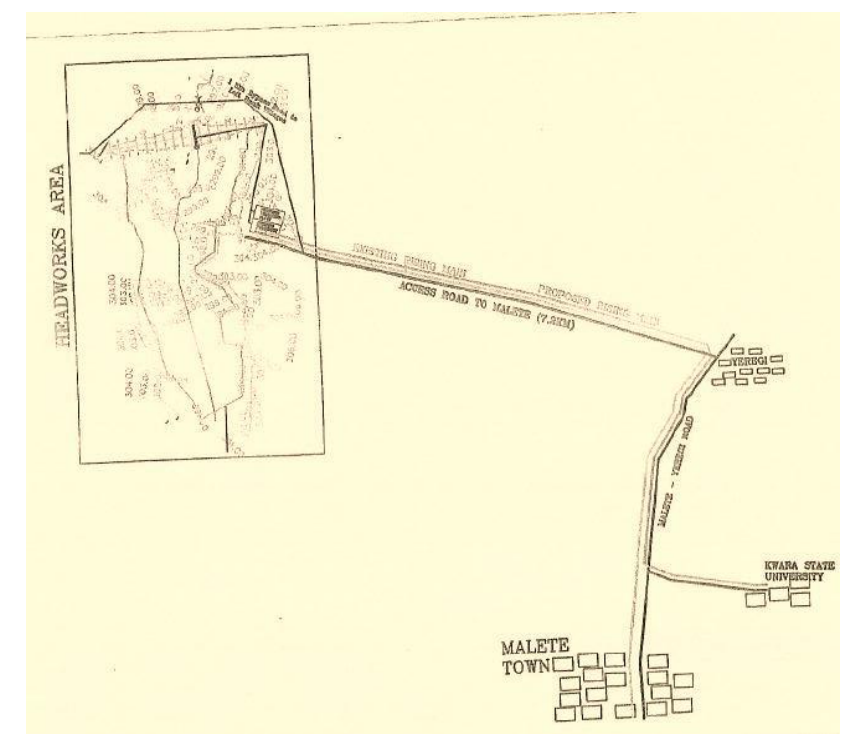

Figure 1. Road map leading to Apodu Reservoir.

\section{Experimental Design}

Ten fishes were randomly selected into a well aerated, rectangular and transparent 50L plastic aquarium containing borehole water (control). According to environmental drilling and remediation services (EDRS) (2016), borehole water is pure, natural and rich in minerals, thus it was used as the negative control. Similarly, 10 fishes each were randomly selected and exposed to $100 \%$ concentration of water sample from Apodu reservoir for a period of 3, 7 and 14 days in static bioassay conditions (with samples renewed every two days). During the time of exposure, 3 fishes were randomly selected at days 3, 7 and 14; and peripheral blood collected from their caudal vein using sterile syringes and needles for the micronucleus (MN) assay.

\section{E. Physicochemical Assessment}

The physicochemical parameters such as water temperature, $\mathrm{pH}$, electrical conductivity and total dissolved solids were measured in situ using Hanna portable pH/ EC/ TDS/ Temperature combined waterproof tester model HI 98129. Transparency levels were also determined using secchi disc with a calibrated rope attached and surface water velocity was measured by the floatation method (Adoni, 1985). The dissolved oxygen and other parameters, as well as heavy metals present in the Apodu reservoir were determined using Hanna multiparameter bench photometer for laboratories model HI 83200 following the protocol on the manure. The result was compared with the borehole water (negative control) and maximum limit approved by standard organizations such as WHO (2006); USEPA, (1996) among others. 


\section{F. Micronucleus Assay}

A thin smear of blood was made onto clean, grease free slides and air-dried for 24 hours at room temperature before fixing in absolute methanol for $20 \mathrm{~min}$ and allowed to air-dry over-night. The slides were stained in $10 \%$ May-Grunwald and 5\% Giemsa. A total number of 1000 erythrocytes were examined for each specimen under a light microscope, with oil immersion at $1000 \times$ magnification for micronucleus (MN) and nuclear abnormalities. The nuclear abnormalities were scored along with $\mathrm{MN}$ as biomarkers of cytogenotoxicity in accordance with Carrasco et al. (1990) and Ergene et al., (2007).

Nuclear and cellular anomalies such as nuclear buds, blebbed nuclei, lobed nuclei, notched nuclei, bi-nucleated erythrocytes and poly-nucleated erythrocytes were recorded on the basis of the criteria described by Da Silva Souza and Fontanetti, (2006). Degenerated cells were discarded. No mortality was observed throughout the experimental period.

Table 1. Physicochemical and heavy metals characteristics of water sample from Apodu reservoir, Malete Nigeria.

\begin{tabular}{|c|c|c|c|c|c|c|}
\hline Parameters & Borehole & Apodu & WHO* & USEPA & ISI & ICMR \\
\hline $\mathrm{pH}$ & 7.01 & 7.05 & $6.50-8.50$ & $6.50-8.50$ & $6.50-8.50$ & $6.50-9.2$ \\
\hline Temperature $\left({ }^{\circ} \mathrm{C}\right)$ & 25.22 & 26.81 & 25.0 & - & - & - \\
\hline Current (A) & - & 5.40 & - & - & - & - \\
\hline Conductivity $(\mu \mathrm{s} / \mathrm{cm})$ & 80 & 88.25 & 1400 & _ & _ & _ \\
\hline Transparency & - & 163.17 & _ & - & - & - \\
\hline TDS (Mg/L) & 576 & 44.74 & - & 500 & - & - \\
\hline $\mathrm{DO}(\mathrm{Mg} / \mathrm{L})$ & 6.80 & 5.80 & $>30$ & & & \\
\hline Nitrate $(\mathrm{Mg} / \mathrm{L})$ & 10.0 & 30.0 & 20 & 10 & & \\
\hline Phosphate $(\mathrm{Mg} / \mathrm{L})$ & 2.00 & 5.00 & 5 & 5 & & \\
\hline Chloride $(\mathrm{Mg} / \mathrm{L})$ & 17.25 & 25 & 25 & & & \\
\hline Magnesium (Mg/L) & 0.33 & 0.53 & 50 & - & 30 & \\
\hline Manganese $(\mathrm{Mg} / \mathrm{L})$ & 0.01 & 0.03 & $0.01-0.5$ & 0.05 & & \\
\hline Calcium (Mg/L) & 68 & 77.25 & 75 & & & \\
\hline Zinc $(\mathrm{Mg} / \mathrm{L})$ & 0.02 & 0.07 & $5.0-10.0$ & 5.0 & & \\
\hline $\operatorname{Nickel}(\mathrm{Mg} / \mathrm{L})$ & 0 & 0 & 0.2 & - & - & - \\
\hline Iron $(\mathrm{Mg} / \mathrm{L})$ & 0 & 0.1 & 0.1 & 0.3 & 0.3 & 1.0 \\
\hline Lead $(\mathrm{Mg} / \mathrm{L})$ & 0 & 0 & 0.05 & 0.02 & 0.1 & 0.05 \\
\hline Copper $(\mathrm{Mg} / \mathrm{L})$ & 0 & 0.02 & 1.0 & 1.3 & 0.05 & 1.5 \\
\hline Cadmium (Mg/L) & 0 & 0 & 0.005 & 0.01 & 0.01 & 0.01 \\
\hline Chromium (Mg/L) & 0 & 0 & - & 0.1 & 0.05 & - \\
\hline
\end{tabular}

"WHO: World health organization; USEPA: United States Environmental Protection Agency; ISI: Independent Schools Protectorate, DO: Dissolved Oxygen, TDS: Total Dissolved Solid.

\section{G. Histopathological Analysis}

Gills, liver and kidney were removed from the exposed Clarias gariepinus in the 3,7 , and 14days period of exposure. The pieces of gills, kidney and liver excised were then rinsed in physiological saline and fixed in aqueous Bouin's fluid for 6,12 and 8 hours respectively and the procedure described by Camargo and Martinez (2007) was employed for the analysis.

\section{H. Statistical Analysis}

Continuous data were expressed as means \pm Standard error (S.E), unless stated otherwise. Data were statistically analysed with statistical package for social science (SPSS) version 21.0. Differences were checked by one-way analysis of variance (ANOVA) using Duncan's multiple-range test (DMRT). The statistical analysis significance for all tests was set at $\mathrm{P}<0.05$. Percentage abnormalities of fish exposed and control groups were calculated using the formula below.

$$
\% \text { abnormalities }=\frac{\text { No of abnormal cell counted } \times 100}{\text { Total number of cell counted }}
$$

\section{RESULT}

\section{A. Physicochemical Analysis Result}

Table 1 presents the physico-chemical parameters and heavy metal analysed in the water sample from Apodu reservoir. The $\mathrm{pH}$ of the water sample and other physico-chemical parameters, as well as all the heavy metals analysed were within the standard limits (WHO, 2006; USEPA, 1996).

Table 2. Summary of frequency of micronuclei and nuclear abnormalities in Clarias gariepinus exposed to water sample from Apodu reservoir

\begin{tabular}{c|c|c|c}
\hline $\begin{array}{c}\text { Exposure } \\
\text { Period(Days) }\end{array}$ & $\begin{array}{c}\mathbf{M N} \\
\mathbf{X} \pm \mathbf{S . ~} \mathbf{E}\end{array}$ & $\begin{array}{c}\mathbf{N A} \\
\mathbf{X} \pm \mathbf{S . ~} \mathbf{E}\end{array}$ & $\begin{array}{c}\text { Total } \\
\text { abnormalities }\end{array}$ \\
\hline $\begin{array}{c}\text { Negative } \\
\text { control }\end{array}$ & $0.50 \pm 0.5$ & $0.0 \pm 0.0$ & $2(0.05)$ \\
\hline 3 & $10.25 \pm 1.25 *$ & $3.25 \pm 1.31 *$ & $41(1.02)$ \\
\hline 7 & $6.00 \pm 3.00 *$ & $5.00 \pm 2.12 *$ & $24(0.60)$ \\
\hline 14 & $9.75 \pm 2.25 *$ & $4.50 \pm 1.55^{*}$ & $39(0.96)$ \\
\hline *Statistical significant $(\mathrm{p}<0.05)$ & \multicolumn{2}{l}{}
\end{tabular}

\section{B. Micronucleus Assay}

The frequency of micronucleated cell and other nuclear abnormalities were not time dependent but statistically significant at all periods of exposure when compared with a negative control. Figure 2 shows the images of some of the abnormalities observed in this study. The negative control 
shows the lowest number of abnormalities but with the highest number of abnormalities was recorded at day 3 (Table 2). The frequency of micronucleated cell (MN) and blebbed nucleus was higher on the $3^{\text {rd }}$ day than those of $7^{\text {th }}$ day and 14th day. Binucleated cell were seen to be higher on the $7^{\text {th }}$ day than the $3^{\text {rd }}$ and $14^{\text {th }}$-day exposure.

\section{Histopathological Analysis}

The histopathological analysis of the gills, liver and kidney of the exposed fish in this study show some histological changes when compared to the negative control (Figure 46). For instance, the gills show some mild alterations such as distortion and infiltration of lymphocytic cells while the liver shows mild distortion of hepatic tissue with interstitial congestion. Abnormal nephron and glomeruli with congestion and vascular dilation of the kidney were also observed.
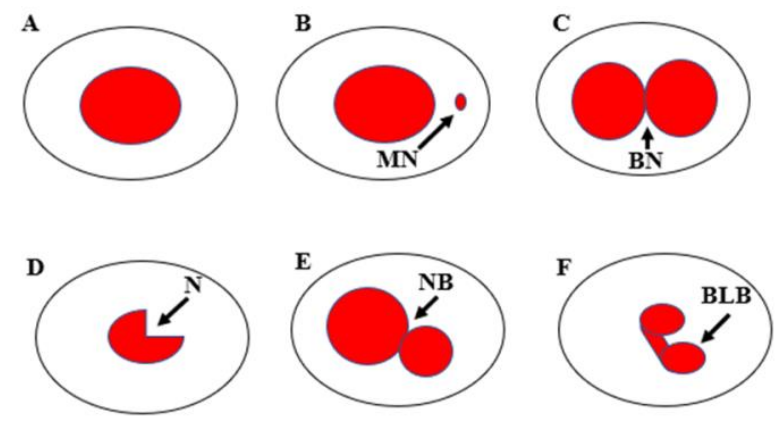

Figure 2. Different abnormalities in the erythrocyte of fish. (A) Normal erythrocyte, (B) Micronucleus (MN) (C) Binucleated (BN) (D) Notched (E) Nuclear bud (F) blebbed.

\section{DISCUSSION}

In developing countries, groundwater and surface water are at serious risk of pollution due to the influx of domestic wastes as well as chemicals used in agricultural activities (Keskin, 2010). These activities not only detrimental to the health of human but also the aquatic organisms. Since fish serve as useful genetic models for the investigation of pollution in aquatic ecosystems (Mitchell and Kennedy, 1992; Park et al., 1993), they are usually employed to determine the extent of pollution of an aquatic environment. The importance of erythrocyte fish micronucleus test cannot be overemphasized because of its role in the monitoring and determination of aquatic pollutants with mutagenic features (De Flora et al., 1993; Saotome and Hayashi, 2003; Pantaleao et al., 2006). Formation of nuclear abnormalities along with $\mathrm{MN}$ in erythrocytes of fish had been considered as possible indicators of genotoxicity; when investigating the effects of pollutants in aquatic species (Al-Sabti and Metcalfe, 1995; Delemos et al., 2007). Thus, in this study, the frequencies of micronucleated erythrocytes and other nuclear abnormalities were used to test the genotoxicity of Apodu reservoir in cultured Clarias gariepinus using micronucleus assay. The frequency of micronuclei and other nuclear abnormalities recorded were not time dependent but statistically significant when compared to the negative control (borehole water). Although, the physico-chemical and heavy metals of the water sample analysed were still within the standard limit permissible (WHO, 2006; USEPA, 1996) but the observed anomalies in the erythrocyte of the fish maybe as a result of nitrate that was detected in the water sample. Therefore, the heavy metals detected maybe as a result of the different anthropogenic activities like direct and indirect indiscriminate discharge of agriculture and domestic waste into the water bodies. This is in line with results earlier finding that stated the sources of heavy metals into water bodies might be from geological rock weathering, human activities such as industrial and/or domestic wastes water discharges or animals where it forms constituent functions in maintaining cytoplasmic veracity (Adeyeye, 1996).

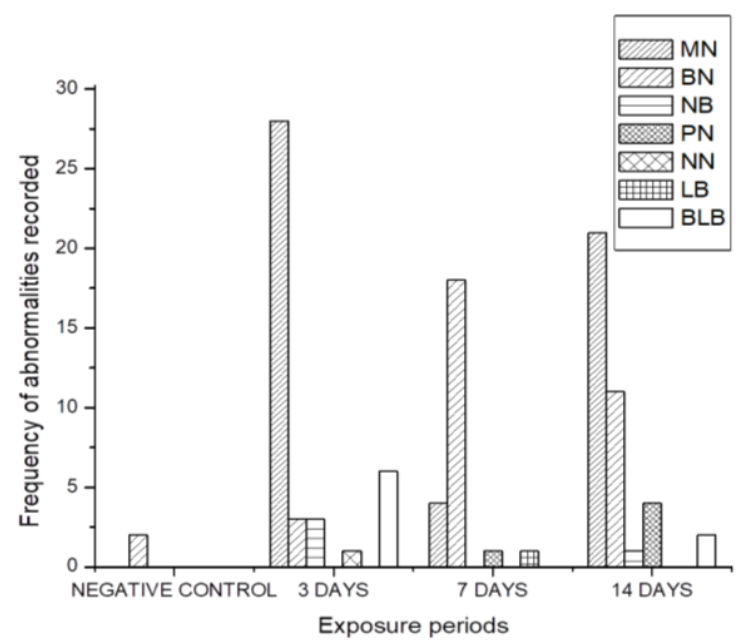

Figure 3. Frequency of micronuclei and other nuclei abnormalities of the exposed fishes. MN: Micronucleus, BN: Binucleated; NB: Nuclear bud; PN: Polynucleated; NN: Notched nuclei, LB: Lobed nuclei; and BLB: Blebbed nuclei.

The micronuclei (MNi) observed in this study may be a signal for DNA damage in the exposed fish since it arises in the mitotic cells from chromosomal fragments or chromosomes that lag behind in anaphase and are not integrated into the daughter nuclei. Some of these are accompanied by apoptosis and necrosis, which may result from the damaged DNA. Our result was in line with some in vivo reports from controlled laboratory conditions and insitu where MNi and NAs were reported; showing genotoxic potentials of polluted water on Oreochromis niloticus,

Synodontis batensoda, Synodontis eupterus, Clarias gariepinus and Clarias angullaris, municipal landfill leachates on $C$. gariepinus; electronic waste leachate and contaminated well water in $C$. gariepinus, textile mill effluent in $O$. niloticus, crude oil in Scophthalmus maximus and Gadus morua and heavy metal in Puntius altus (Anifowoshe et al., 2019; Anifowoshe et al., 2018; Bakare et al., 2013; Alimba et al., 2011; Ozkan et al., 2011; Barsiene et al., 2006; Cavas and Ergene-Gozukara, 2003). 
A

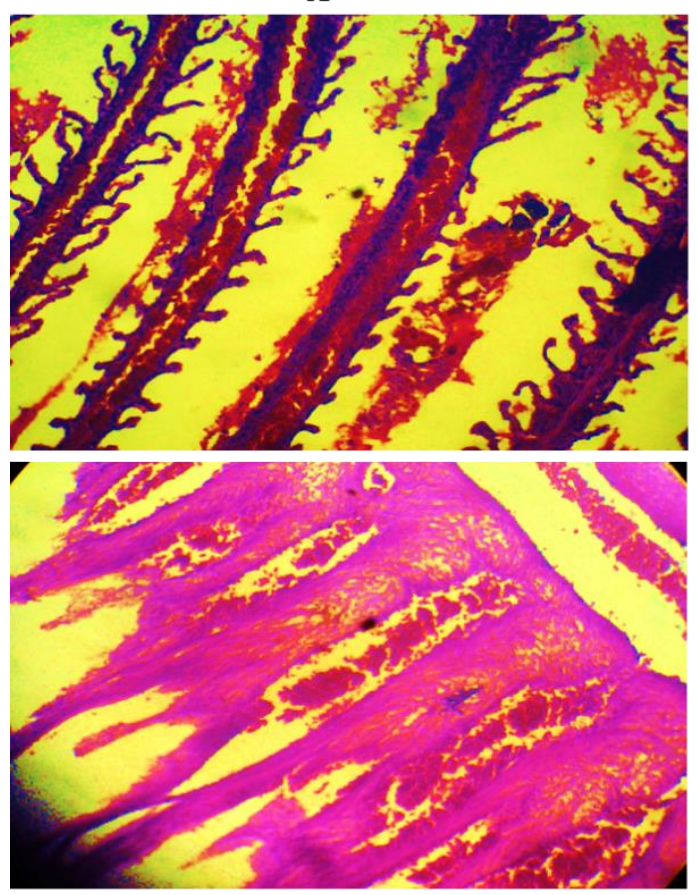

C

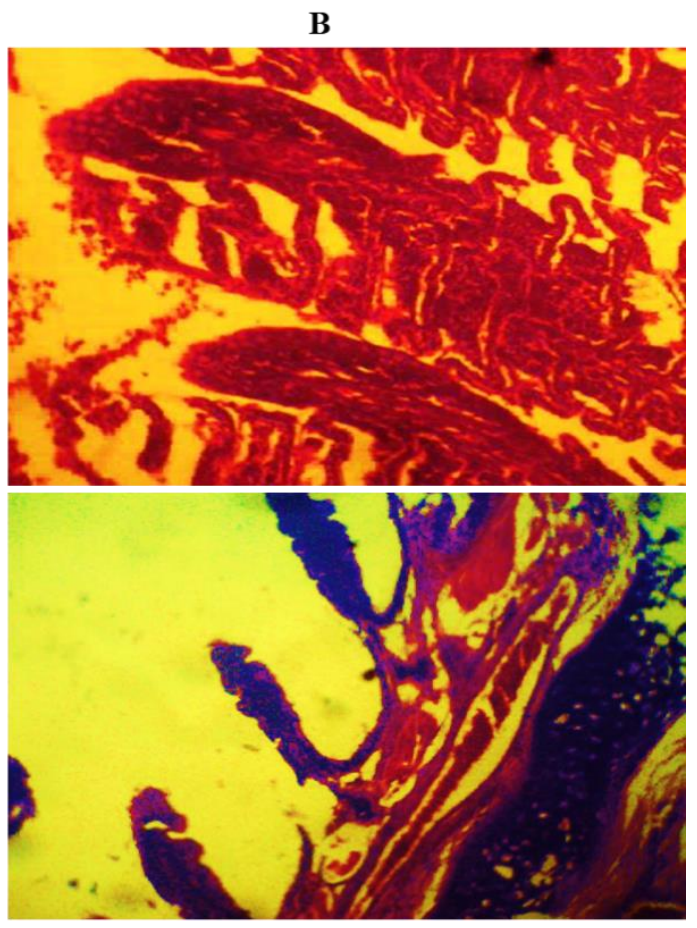

D

Figure 4. Histopathological of the gills of C. gariepinus exposed to water sample from Apodu reservoir (Mag x 400). (A) $C$. gariepinus gills (Negative control). Micrograph shows epithelia lining and cartilage. (B) C. gariepinus gills at 3 days exposure to waste sample. Micrograph section shows cartilage and area of lymphocytic infiltration. (C) C. gariepinus gills at 7 days exposure to water sample. Micrograph shows areas of lymphocyte infiltration with ciliated cuboidal epithelia lining. (D) C. gariepinus gills at 14days exposure to the water sample. Micrograph shows distortion of lymphocytic cells.

Other NAs such as blebbed and notch nuclei observed in the C. gariepinus may be associated with aneuploidy probably originated from tubulin failure, hence extruding from the nucleus as damage (Ventura et al., 2008). Also binucleated observed in the erythrocytes may indicate cytokinesis blocking of a normal dividing cell during $\mathrm{M}$ phase of the cell cycle (cytotoxicity) by constituents of the toxic metals (Alimba et al., 2011; Barsiene et al., 2006; Ozkan et al., 2011). The presence of NAs can lead to genetic imbalance and carcinogenesis (Rodilla, 1993). Thus they complement the scoring of $\mathrm{MN}$ in cytogenotoxicity studies (Cavas, 2008). In recent time, research focus on possible mechanisms of complex mixture induced DNA damage.

Among the important classes of pollutants, heavy metals are in the narrow window between their essentiality and toxicity (Aanand et al., 2012). Heavy metals due to their potential toxicity produce biochemical changes in the organs of animals, and continuous exposure may alter genetic composition (Ebenezer, 2003). The source of heavy metals at the study sites is mainly of exogenous origin, due to either agricultural influx and/or sewage via surrounding cultivated lands. The estimated heavy metals present in the water sample from Apodu reservoir was in the order of $\mathrm{Ca}>\mathrm{Mg}>\mathrm{Fe}>\mathrm{Zn}>\mathrm{Mn}>\mathrm{Cu}>\mathrm{Ni}=\mathrm{Pb}=\mathrm{Cd}=\mathrm{Cr}$. Nitrate pollution (NO3-) was also observed in the reservoir and this might be as a result of agricultural practices which utilize various types of pesticides and fertilizers (ammonium nitrate, ammonium sulfate, diammonium phosphate, urea (nitrogenous fertilizer) in this area (Keskin, 2010). The result of the physicochemical parameters of the water sample from Apodu reservoir (Table 1) compared to the maximum limit approved by USEPA, (1996); WHO, (2006) and others shows that the water sample is less toxic as all results were within the maximum permissible limit.

The histopathological analysis of the gills, liver and kidney in this study shows some mild lesion such as lymphocyte infiltration and distortion, muscle congestion, distortion, vascular dilation, abnormal nephron and glomeruli (Figure 4-6). All the histopathological observations indicated that exposure to the water sample from Apodu reservoir caused mild effect to the gill, liver and kidney tissues of $C$. gariepinus. This corroborates with the observation of Jana and Bandopadhyaya (1987) which reported that gill is a vital tissue because of its direct contact with water and any effect or agency has to go through it to come into the fish body. According to Cladwell (1997), the end result would be reduced flow of oxygen-enriched water to lamellar tissues and ultimately, a reduction in the fish's performance capacity. Therefore, disturbance of living processes at the molecular and subcellular levels of the biological organization by xenobiotics can lead to cell injury, resulting in degenerative and neoplastic diseases in target organs (Pacheco and Santos, 2002). 

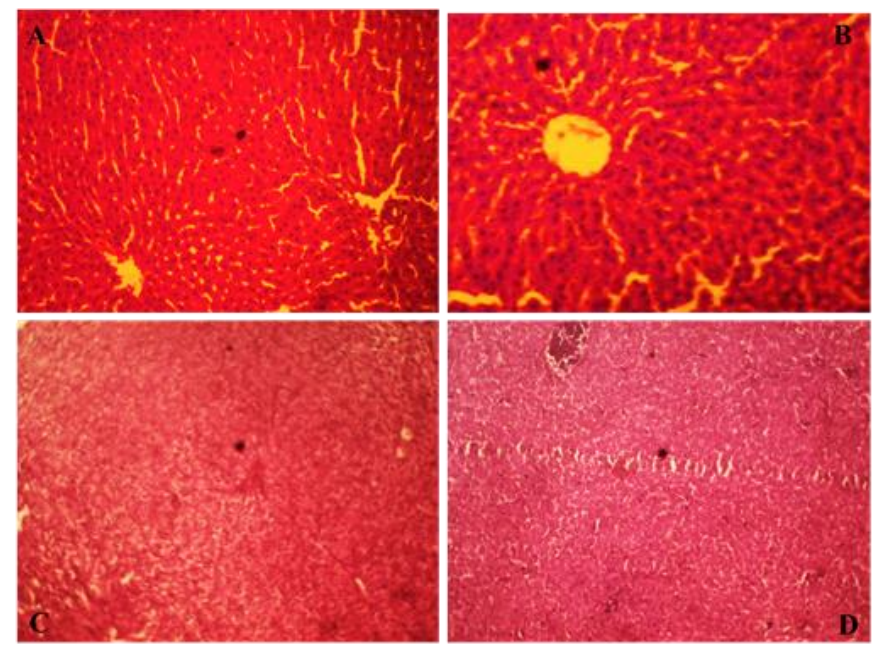

Figure 5. Histopathological of the liver of $C$. gariepinus exposed to water sample from Apodu reservoir (Mag x 400). (A) C. gariepinus liver (Negative control). Micrograph shows normal hepatocytes with no interstitial congestion. (B) C. gariepinus liver at day 3. Micrograph shows normal hepatocytes with little interstitial congestion (C) C. gariepinus liver at 7 days exposure to water sample. Micrograph shows irregular polyhedral plates of hepatocytes with central vein. There are portal triads at the edge of hepatocytes. (C) C. gariepinus liver at 14 days exposure to water sample. Micrograph shows mild distortion of hepatic tissue with interstitial congestion scan.

\section{CONCLUSION}

This study reports a low concentration of heavy metal pollution in Apodu reservoir as seen in the frequency of nuclear abnormalities observed. The level of nutrient (nitrates) and heavy metals present in the tested samples provoked the observed DNA damage and the mild histopathological alterations. The pollution occurs at levels that cannot constitute serious health problems for the inhabitants of this area. However, fishes inhabiting this area are subjected to stress due to indiscriminate discharges of wastes from household and nutrient leaching by the farmers. Therefore, more efforts should be directed towards remediating the water body and stopping the influx from the agricultural land into the reservoir.

\section{ACKNOWLEDGMENT}

We wish to thank the authority of the Department of Zoology, University of Ilorin, Ilorin, Nigeria for making available the facilities used for this study. We also wish to thank the people of Apodu reservoir for their hospitality.
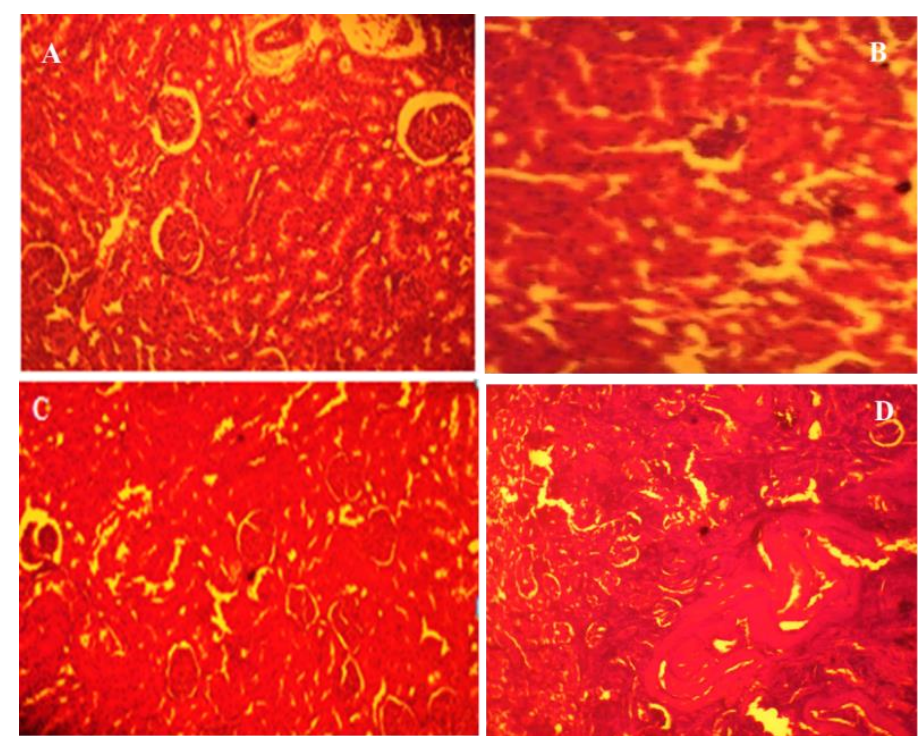

Figure 6. Histopathology of the kidney of fish exposed to water sample from Apodu reservoir (Mag x 400). (A) C. gariepinus kidney (Negative control). Micrograph section shows renal tissue composed of numerous glomeruli and renal tubules. (B) C. gariepinus kidney on day 3 . Micrograph section shows renal tissue composed of cortex and medulla. The cortex shows numerous glomeruli and tubules are lying back to back are lined by cuboided epithelium cells. (C) C. gariepinus kidney after 7 days exposure to the water sample. Micrograph shows renal tissue composed of cortex and medulla. The cortex shows numerous glomeruli and tubules are laying back to back are lined by cuboided epithelium cells. (D) C. gariepinus kidney after 14days exposure to water sample. Micrograph shows mild distortion and abnormal nephron and glomeruli with congestion and vascular dilation.

\section{CONFLICT OF INTEREST}

The authors declare no conflict of interest

\section{REFERENCES}

Aanand, S., Purushothaman, S., Pal, A.K., Rajendran, K.V. (2012). Toxicological studies on the effect of copper, lead and zinc on selected enzymes in the adductor. Mutation Research, 746: 7- 14.

Adeyeye, E. (1996). Determination of major elements in Illisha africana fish, associated water and soil sediments from some freshwater ponds. Bangladesh Journal of Scientific and Industrial Research, 31: 171-184.

Adoni, A.D. (1985). Work Book on Limnology. Bandna Printing Service, New Delhi. 216 pp.

Al-Sabti, K. (1991). Handbook on genotoxic effects and fish chromosome. Jozef Stefan Institute, Jamova.

Al-Sabti K., Metcalfe C.D. (1995). Fish micronuclei for assessing genotoxicity in water. Mutation Research, 343: 121-135.

Alimba, C.G., Saliu, J.K., Adesanya, A., and Bakare, A.A. (2011). Evaluation of Genotoxicity of municipal landfill leachate by micronucleus test using Clarias gariepinus. Research in Environment and Life Sciences, 4: 1-6.

Anifowoshe, A.T., Oladipo, S.O., Owolodun, O.A., Akinseye, K.M., Olafimihan, T.F., Sidiq, A.G., Muhammed, A.A., Asa, T.A., Mustapha, M.K. (2018). Eco-genotoxicological assessments of some selected fish species from Apodu Reservoir, Malete, North Central, Nigeria. Manila Journal of Science. (11),1-14.

Anifowoshe, A.T., Oladipo, O.S., Adebayo, M.O., Eboh, S.O., Abdussalam, R.A., Adegbenro, M.A., Ojo, I.T., Adetunji, K.A., Yekeen, H.O., Adebiyi, K.A., Tijani, S.O., Oladipupo, R.O. Abdulkareem, S.I. (2019). Induction of Micronuclei, Base-pair Substitution Mutation and Excision-repair Deficient by Polluted Water from Asa River in Nigeria. Annal of Science Technology, 4 (2) 68-77. 
Bakare, A.A., Alabi, O. A., Gbadebo, A.M., Ogunsuyi, O.I., Alimba, C.G. (2013). In Vivo Cytogenotoxicity and Oxidative Stress Induced by Electronic Waste Leachate and Contaminated Well Water. Challenges, 4, 169-187.

Barsiene, J., Dedonyte, V., Rybakovas, A., Andreikenaite, L., Andersen, O.K. (2006). Investigation of micronuclei and other nuclear abnormalities in peripheral blood and kidney of marine fish treated with crude oil. Aquatic Toxicology, 78, S99-S104.

Boyd, C.E. (1990). Water Quality in Ponds for Aquaculture, Birmingham Publishing Co., Birmingham, Alabama.

Carrasco, K.R., Tilbury, K.L., Myers, M.S. (1990). Assessment of the piscine micronucleus test as in situ biological indicator of chemical contaminant effects. Canadian Journal of Fisheries and Aquatic Sciences, 47: 2123-2136.

Camargo, M.M.P., Martinez, C.B.R. (2007). Histopathology of gills, kidney and liver of a Neotropical fish caged in an urban stream. Neotropical Ichthyology, 5(3), 327-336.

Cavas, T. (2008). In vivo genotoxicity of mercury chloride and lead acetate: Micronucleus test on acridine orange stained fish cells. Food and Chemical. Toxicology, 46, 352-358.

Cavas, T., Ergene-Gozukara, S. (2003). Evaluation of the genotoxic potential of lambda- cyhalothrin using nuclear and nucleolar biomarkers on fish cells. Mutation Research, 534: 93-99.

Cladwell, C.A. (1997). Aromatic hydrocarbon pathology in fish following a large spill into the Nemadji river, Wisconsin, USA. Bullentin of Environmental Contamination and Toxicology, 58: 574-581.

Da Silva Souza, T., Fontanetti, C.S. (2006). Micronucleus test and observation of nuclear alterations in erythrocytes of Nile tilapia exposed to waters affected by refinery effluent, Mutation Research, $605(1-2), 87-93$.

De Flora, S., Vigario, L., D'Agostini, F., Camoirano, A., Bagnasco, M., Bennecelli, C., Arillo, A. (1993). Multiple biomarkers in fish exposed in situ to polluted river water. Mutation Research, 319: 167-177.

Delemos, C.T., Rodel, P.M. Terra, N.R., Erdtmann, B. (2007). Evaluation of basal micronucleus frequency and hexavalent chromium effects in fish erythrocytes. Environmental Toxicology and Chemistry, 20, $1320-1324$.

EDRS (2016). Retrieved from www.domesticboreholes.co.za/the-topbenefits-of-borehole-water/

EFSA, (2005). Opinion of the Scientific Panel on contaminants in the food chain [CONTAM] related to the safety assessment of wild \& farmed fish. Retrived fromhttp://www.efsa.europa.eu/EFSA/efsa_locale1178620753812_1178620762697.htm.

Ebenezer M. (2003). A comparative study of heavy metals in the water of an urban and rural pond. Journal of Ecobiology 15 (6), 407-412.

Ergene, S., Cavas, T., Celik, A., Koleli, N., Aymak, C. (2007). Evaluation of river water genotoxicity using piscine micronucleus test. Environmental and Molecular Mutagenesis, 48: 421-429.

Jana, S., Bandopadhyaya, N. (1987). Effect of heavy metals on some biochemical parameters in the freshwater fish, Clarias punctatus. Environment and Ecology, 5(3), 488-493.

Javed, M., Usmani, N. (2011). Accumulation of heavy metals in fishes: a human health concern. International Journal of Environmental Sciences, 2:659-670.

Keskin, T. E. (2010). Nitrate and heavy metal pollution resulting from agricultural activity: a case study from Eskipazar (Karabuk, Turkey). Environmental Earth Sciences. 61:703-721.

Lam, P.K.S., Gray, J.S. (2003). The Use of Biomarkers in Environmental Monitoring Programmes. Marine Pollution Bulletin, 46: 182-186.

Mayon, N., Bertrand, A., Leroy, D., Malbrouck, C., Mandiki, S.N.M., Silvestre, F., Kestemont, P. (2006). Multiscale approach of fish responses to different types of environmental contaminations: a case study. Science Total Environment, 367: 715-731.

Mitchell, S., Kennedy, S. (1992). Tissue concentrations of organochlorine compounds in common seals from the coast of Northern Ireland. Science Total Environment, 115: 235-240.

Osman, A.G.M., Abuel-Fadl, K.Y., Kloas, W. (2012). In situ evaluation of the genotoxic potential of the river Nile: II. Detection of DNA strandbreakage and apoptosis in Oreochromis niloticus niloticus (Linnaeus, 1758) and Clarias gariepinus (Burchell,1822). Mutation Research, 747: $14-21$.
Ozkan, F., Gündüz, S.G., Berköz, M. Hunt, A.O. (2011). Induction of micronuclei and other nuclear abnormalities in peripheral erythrocytes of Nile tilapia, Oreochromis niloticus, following exposure to sublethal cadmium doses. Turkish Journal of Zoology, 35: 585-592.

Pacheco M., Santos M. A. (2002). Biotransformation, genotoxic and histopathological effects of environmental contaminants in European eel, Anguilla anguilla L. Ecotoxicology and Environmental Safety, 53, 331-347.

Pantaleao, S.M., Alcantara, A.V., Alves, J.P., Spano, M.A. (2006). The piscine micronucleus test to assess the impact of pollution on the Japaratuba river in Brazil. Environmental and Molecular Mutagenesis, 47(3), 219-224.

Park, E., Lee, J., Etoh, H. (1993). Fish Cell line (ULF-23HU) Derived from the Fin of the Central Mudminnow (Umbra limi): Suitable Characteristics for Clastogenicity Assay. In Vitro Cellularand Developmental Biology, 25: 987- 994.

Saotome, K., Hayashi, M. (2003). Application of a sea urchin micronucleus assay to monitoring aquatic pollution: influence of sample osmolality. Mutagenesis. 18(1): 73-6.

Sarangi, P.K., Patnaik R, Porichha S.K., Prasad R. (2001). Genotoxicity of malathion in Channa Punctatus cultured in vivo Perspective in Cytology and Genetics, 10, 835-844 (Editors G.K.Manna and S. C. Roy, AICCG Publication, Kalyani University.

Rodilla, V. (1993). Origin and evolution of binucleated cells and binucleated cell with micronuclei in cisplatin-Treated CHO cultures. Mutation Research, 300: 281-291.

Rybakovas, A., Barsiene, J., Lang, T. (2009): Environmental Genotoxicity and Cytotoxicity in Offshore Zones of the Baltic and North Seas. Marine Environmental Research, 68: 246-256.

WHO (2006). Guideline for Drinking Water quality (electronic Resource). Incorporating first Addendum 1, Recommendations 3rd retrieved from http://www.whglibdoc.who.int/publications/2006/9241546964.eng.pd.

United States Environmental Protection Agency (USEPA) (1996): Acid digestion of sediments, sludges and soils, Method-3050B.USEPA, Washingtn, DC.

Ventura, B.C., Angelis, D.F., Marin-Morales, M.A. (2008): Mutagenic and genotoxic effects of the atrazine herbicide in Oreochromis niloticus (Perciformes, Cichlidae) detected by the micronuclei test and the comet assay. Pesticide Biochemistry and Physiology, 90, 42-51. 